\section{A HITHERTO UNRECORDED SIGHTING OF THE COMMON POCHARD AYTHYA FERINA (LINNAEUS, 1758) (AVES: ANSERIFORMES: ANATIDAE) IN VEDANTHANGAL BIRD SANCTUARY, TAMIL NADU, INDIA}

Samidurai Jayakumar ${ }^{1}$, Subramanian Muralidharan ${ }^{2} \&$ Santhanakrishnan Babu ${ }^{3}$

${ }^{1}$ A.V.C. College (Autonomous), Mannampandal, Mayiladuthurai, Tamil Nadu 609305, India

${ }^{2}$ Division of Ecotoxicology, ${ }^{3}$ Division of Ornithology,

Sálim Ali Centre for Ornithology and Natural History, Anaikatty, Coimbatore, Tamil Nadu 641108, India

1 jayakumar.msv@gmail.com (corresponding author),

2ecot_mur@yahoo.com, ${ }^{3}$ sanbabs@gmail.com

Vedanthangal Bird Sanctuary $\left(12.5449^{\circ} \mathrm{N} \&\right.$ $79.8564^{\circ} \mathrm{E}$ ), located $85 \mathrm{~km}$ south-west of Chennai City, with 30 ha of water spread area has been home to around 30,000 birds during the peak breeding season (November to March) for over two centuries. As part of a long-term waterbird survey in the sanctuary, on 10 January 2009 at $1430 \mathrm{hr}$, we came across a duck that had red head with grey banded bill in a small patch of open water. To our surprise, we identified it as the Common Pochard Aythya ferina. Before the bird flew away from the sanctuary, the first author managed to get the bird trapped in his camera (NIKON D50 with 300 mm NIKOR Tele lens) (Image 1). Perusal through the available records on the Common Pochard's occurrence in Tamil Nadu revealed that the bird has been sighted for the first time in Vedanthangal Bird Sanctuary.

Common Pochard is one of the four species of the genus Aythya that winters in India. The global population of this species is estimated at $22,00,000$ $25,00,000$ individuals (BirdLife International 2013) and it has been categorized as Least Concern by IUCN. The breeding range of this species spans across the temperate regions of Eurasia, south-east Russia and north east China. It is a winter visitor to India and arrives by late October and departs by the end of March. It is quite common in northwestern India and more sparsely in Assam and Manipur. However, it is irregular in the south (Ali \& Ripley 1969; Rasmussen \& Anderton 2005; Rahmani \& Islam 2008; BirdLife International 2013). None of the earlier studies have recorded the Common Pochard in Vedanthangal Bird Sanctuary. However, there exist a few records from other parts of the state viz., Red Tank in Coimbatore District (Pillay 1962), Kunnathur, Orappanur and Vellari Tanks in Madurai District (Narayanan 1994), Thermal camp II in Tuticorin District (Wesley 1997), Karaivetti Bird Sanctuary in Perambalur District (Rahmani \& Islam 2008) and Chenbarambakkam, Enathur and Madurantakam tanks in Kanchipuram District (Rahmani \& Islam 2008) (Table
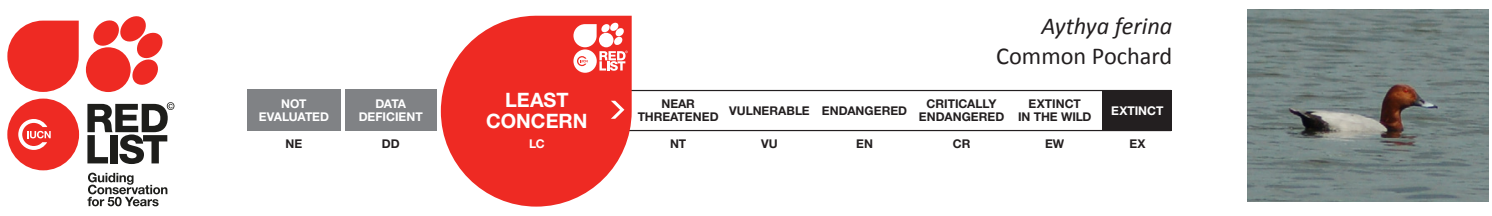

DOI: http://dx.doi.org/10.11609/JoTT.o3662.6485-7 | ZooBank: urn:Isid:zoobank.org:pub:64815A16-353D-4231-9D46-1FFA57E376D9

Editor: S. Balachandran, Bombay Natural History Society, Mumbai, India.

Date of publication: 26 October 2014 (online \& print)

Manuscript details: Ms \# 03662 | Received 14 June 2013 | Final received 04 October 2014 | Finally accepted 06 October 2014

Citation: Jayakumar, S., S. Muralidharan \& S. Babu (2014). A hitherto unrecorded sighting of the Common Pochard Aythya ferina (Linnaeus, 1758) (Aves: Anseriformes: Anatidae) in Vedanthangal Bird Sanctuary, Tamil Nadu, India. Journal of Threatened Taxa 6(11): 6485-6487; http://dx.doi.org/10.11609/JoTT.03662.6485-7

Copyright: @ Jayakumar et al. 2014. Creative Commons Attribution 4.0 International License. JoTT allows unrestricted use of this article in any medium, reproduction and distribution by providing adequate credit to the authors and the source of publication.

Funding: Ministry of Environment and Forest, Government of India, New Delhi.

Competing Interest: The authors declare no competing interests.

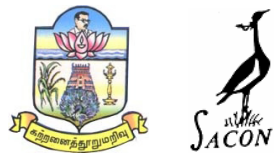

Acknowledgements: We are grateful to the Ministry of Environment \& Forests, Government of India for financial support. We express our sincere gratitude to the Principal Chief Conservator of Forests, Tamil Nadu for granting permission. We are grateful to the director and scientists, SACON, Coimbatore for their support. We appreciate Mr. Murugan, bird watcher for his assistance in the field. 


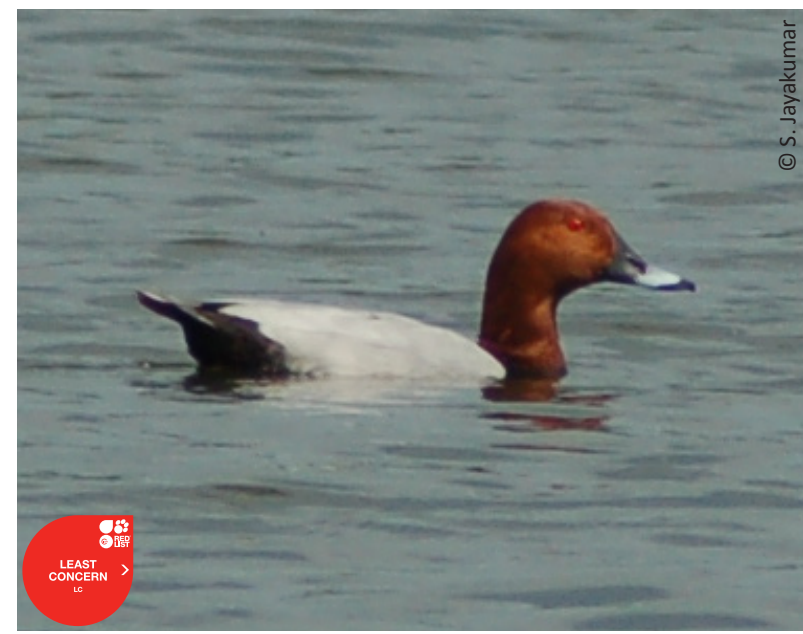

Image 1. Photographic evidence of Common Pochard in Vedanthangal Bird Sanctuary, Tamil Nadu

1, Fig. 1). Ten out of 12 sightings in Tamil Nadu during the last 23 years were outside protected wetlands such as tanks, lakes and ponds during the post-monsoon period (January). Koonthankulam Bird Sanctuary is yet another important breeding and foraging grounds for several species of wetland associated birds in the southern districts of Tamil Nadu. However, during an intensive study in this area between 2009 and 2010, the Common Pochard was never sighted (Jayakumar 2013). The available published records on this species indicate that the southernmost and southwestern winter distribution ranges for this species in India are respectively Tuticorin $\left(8.7349^{\circ} \mathrm{N} \& 78.1207^{\circ} \mathrm{E}\right)$ and Coimbatore $\left(10.9805^{\circ} \mathrm{N}\right.$ $\left.\& 76.9610^{\circ} \mathrm{E}\right)$. There is no record of this species from

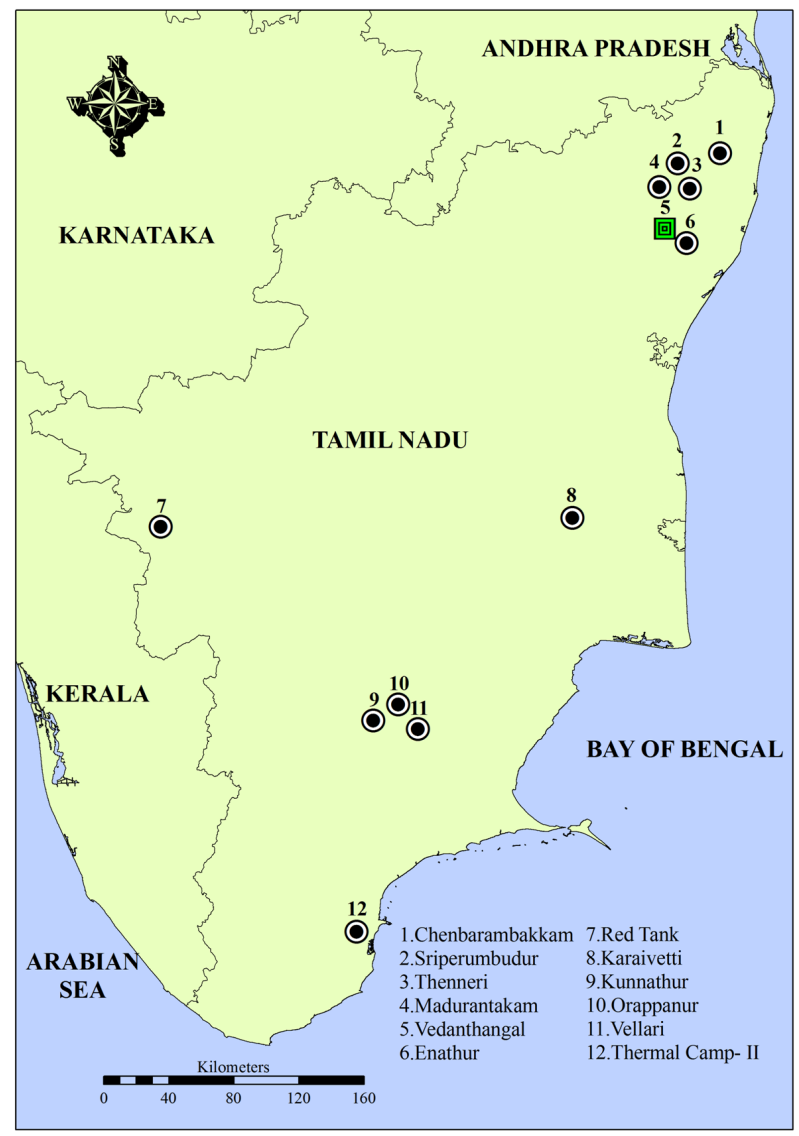

Figure 1. Map showing the distribution of Common Pochard in Tamil Nadu.

Kerala (Sashikumar et al. 2011).

According to Ali \& Ripley (1969), the Common Pochard is one of the commonest diving ducks which

Table 1. Sighting records of Common Pochard in Tamil Nadu

\begin{tabular}{|c|c|c|c|c|c|}
\hline & Location & $\begin{array}{l}\text { Month \& Year of } \\
\text { sightings }\end{array}$ & Area status & Source & $\begin{array}{c}\text { No. of } \\
\text { individuals }\end{array}$ \\
\hline 1 & Red Tank, Coimbatore & November 1961 & Unprotected & Pillay 1962 & 6 \\
\hline 2 & Chenbarambakkam Lake, Kanchipuram & October 1984 & Unprotected & Rahmani \& Islam 2008 & 4 \\
\hline 3 & Enathur Tank, Kanchipuram & January 1984 & Unprotected & Rahmani \& Islam 2008 & 300 \\
\hline 4 & Vellari Tank, Madurai & 1990 & Unprotected & Narayanan 1994 & - \\
\hline 5 & Sriperumbudur Lake, Kanchipuram & January 1991 & Unprotected & Rahmani \& Islam 2008 & 108 \\
\hline 6 & Thenneri Tank, Kanchipuram & January 1991 & Unprotected & Rahmani \& Islam 2008 & 52 \\
\hline 7 & Madurantakam Lake, Kanchipuram & January 1991 & Unprotected & Rahmani \& Islam 2008 & 915 \\
\hline 8 & Karaivetti Bird Sanctuary, Perambalur & - & Protected & Rahmani \& Islam 2008 & - \\
\hline 9 & Kunnathur Tank, Madurai & 1991 & Unprotected & Narayanan 1994 & 400 \\
\hline 10 & Orappanur Tank, Madurai & 1991 & Unprotected & Narayanan 1994 & - \\
\hline 11 & Thermal Camp- II, Tuticorin & January 1991 & Unprotected & Wesley 1997 & - \\
\hline 12 & Vedanthangal Bird Sanctuary, Kanchipuram & January 2009 & Protected & Present study & 1 \\
\hline
\end{tabular}


prefers open water of jheels and reservoirs with submerged vegetation. Earlier sightings of this species from Tamil Nadu summarized in Table 1 also indicate that they are habitat specialists. Although Vedanthangal serves as a potential habitat for nesting birds, it has limited open water area with submerged vegetations. Therefore, it could be said that due to non-availability of suitable open water habitat, the Common Pochard did not frequent the Vedanthangal Bird Sanctuary. As its occurrence was documented through a single sighting, further monitoring and surveillance in and around the sanctuary during winter is needed to elucidate the fact whether its occurrence at Vedanthangal was accidental or is regular.

\section{References}

Ali, S. \& S.D. Ripley (1969). Hand book of the birds of India and Pakistan. Vol. 3. Oxford University Press, New Delhi, xiv+327pp.
BirdLife International (2013). IUCN Red List for birds. Downloaded from http://www.birdlife.org on 09 June 2013.

Jayakumar, S. (2013). Organochlorine pesticides, population and reproductive success of fish-eating birds in select heronries in Tamil Nadu. PhD Thesis, Bharathiar University, Coimbatore (Unpublished).

Narayanan, T.B. (1994). Southern most record of Common Pochard Aythya ferina (Linnaeus, 1758) and Tuffed duck Aythya fuligula (Linnaeus, 1758) in Madurai District, Tamil Nadu. Journal of Bombay Natural History Society 91(3): 452-453.

Pillay, B.S. (1962). Wigeon Anas penelop (Linnaeus, 1758) and Redheaded Pochard Aythya ferina (Linnaeus, 1758) at Coimbatore, southern India. Journal of Bombay Natural History Society 59: 286.

Rahmani, A.R. \& M.Z. Islam (2008). Duck, Geese and Swans of India: Their Status and Distribution. Indian Bird Conservation Network. Bombay Natural History Society. Royal Society for the Protection Birds. BirdLife International, Oxford Press, 374pp.

Rasmussen, P.C. \& J.C. Anderton (2005). Birds of South Asia. The Ripley Guide. Smithsonian Institution and Lynx Edition, Washington. D.C \& Barcelona, 375pp.

Sashikumar, C., J. Praveen, M.J. Palot \& P.O. Nameer (2011). Birds of Kerala: Status and Distribution. DC Books, Kottayam, 835pp.

Wesley, H.D. (1997). Birds in and around thermal Camp II at Tuticorin. Newsletter for Bird Watchers 37: 5-8. 